\title{
The Stem Cell Environment: Kinetics, Signaling and Markers
}

\author{
George D. Wilson ${ }^{1,2}$, John M. Robertson', \\ Harry Wasvary ${ }^{3}$ and Bryan J. Thibodeau ${ }^{2}$ \\ ${ }^{1}$ Department of Radiation Oncology, \\ ${ }^{2}$ Beaumont BioBank, \\ ${ }^{3}$ Department of Colon and Rectal Surgery, \\ William Beaumont Hospital, \\ Royal Oak, Michigan, \\ USA
}

\section{Introduction}

Colorectal cancer (CRC) is one of the commonest cancers and the third leading cause of cancer death. In the developed world more than 1 million individuals will develop colorectal cancer every year (Parkin et al. 2005). According to the Surveillance, Epidemiology and End Results (SEER) Program database, the prognosis of CRC has an improving trend. 5-year survival rates have risen from $56.5 \%$ for patients diagnosed in the early 1980 s to as much as $63.2 \%$ for those diagnosed in the early 1990 s and most recently to $64.9 \%$. Currently, rectal cancer is usually discussed together with colon cancer and historically accounted for more than $50 \%$ of CRCs. However, this has now decreased to less than colon cancers; in a recent review the incidence in the European Union was approximately $35 \%$ of the total CRC incidence (Glimelius and Oliveira 2009). The prognosis of rectal cancers is worse than that of colon cancers (Enblad et al. 1988), and the clinical treatment of rectal cancers is different from that of colon cancers (Vo et al. 2010). Rectal cancer is a very different tumor from colon cancer because of the anatomical narrow confines of the pelvis, the proximity of the genitourinary organs and nerves, and the anal sphincter mechanism. Oncological cure remains the primary aim of treatment for rectal cancer, but sparing of the anal sphincters with adequate bowel, genitourinary, and sexual function is also taken into consideration.

Pre-operative staging is crucial to stratify patients into one of three treatment strategies: patients whose tumors are superficial require surgery alone, patients with operable tumors but at an increased risk of local recurrence require short course radiotherapy and then optimal surgery, and thirdly those with more locally advanced rectal cancers with close or involved circumferential resection margins require neoadjuvant chemoradiation (CRT) followed by surgery. Early detection and treatment is vital to better survival. The five year survival rate of patients diagnosed with early stage CRC is approximately $90 \%$ as opposed to close to $10 \%$ for those diagnosed with locally advanced or metastatic disease. Indeed, the median survival of patients with metastatic CRC is only two years despite multiple available treatment modalities, including surgical resection, chemoradiation, monoclonal 
antibodies to tumor growth factors, and liver-directed therapies for metastatic disease. Few patients are sensitive to these therapies and even fewer are cured.

The early pathway to CRC tumorigenesis has been well elucidated by the seminal work of Vogelstein and colleagues in which a single colorectal epithelial cell acquires a mutation in the tumor suppressor APC gene (Jones et al. 2008). The cells subsequently acquire a complex array of molecular mutations and quickly acquire the potential to metastasize (Jones et al. 2008). The concept of clonal evolution which postulated that tumor progression results from acquired genetic variability within the original mutated clone allowing sequential selection of more aggressive sub-lines provided a ready explanation for the relentless advance toward ever more malignant behavior within established tumors (Nowell 1976) including colorectal cancer (Fearon and Vogelstein 1990). However, prior to the theory of clonal evolution, the cancer stem cell concept had been formulated to account for the heterogeneity, resistance to treatment, and dormancy exhibited by many solid tumors (Pierce and Speers 1988). The CSC concept postulated that, similar to the growth of normal proliferative tissues such as bone marrow, skin or intestinal epithelium, the growth of tumors is driven by limited numbers of dedicated stem cells that are capable of self-renewal. More recently, the CSC concept has gained more momentum due to studies in leukemia. These studies showed that engraftment of tumors in an immunodeficient mouse could only be initiated from a specific subpopulation of CD34+CD38- cells and led to the identification of a CSC in acute myeloid leukemia (AML) (Bonnet and Dick 1997). In 2003, Clarke and colleagues (Al-Hajj et al. 2003) applied the same concepts and experimental approaches to a solid breast cancer tumor and showed that as few as $100 \mathrm{CD} 44^{+} \mathrm{CD} 24^{-/ \text {low }}$ cells were tumorigenic, whereas tens of thousands of cells with alternate phenotypes were not. CSC theory and clonal evolution are not mutually exclusive, and it is likely that a single tumor may contain multiple cancer stem cell clones that are genetically distinct. However, they will always have a common ancestor in the stem cell that sustained the first oncogenic mutation and became the origin of the tumor.

\section{Cancer stem cell theory}

Stem cell concepts and their application to cancer is not a new subject (Clevers 2011; Wicha et al. 2006). As far back as the nineteenth century, it was recognized that tumors exhibit profound histological heterogeneity. In the 1930's, it was discovered that a single cell from a mouse tumor could initiate a new tumor in a recipient mouse. Subsequently, several studies showed that the number of cells with tumor-initiating properties in solid tumors and leukemias was found to be variable but low ( $10^{3}$ to $10^{7}$ cells). The resulting tumors typically showed the morphologic heterogeneity of the original tumor.

CSCs possess several key properties of normal tissue stem cells including self-renewal, unlimited proliferative potential, infrequent or slow replication, resistance to toxic xenobiotics, enhanced DNA repair capacity, and the ability to give rise to daughter cells that differentiate. However, unlike highly regulated tissue stem cells, CSCs demonstrate deregulated self-renewal/differentiation processes and generate daughter cells that arrest at various stages of differentiation. The progeny of the stem cells make up the bulk of the tumor and are characterized by rapid replication, limited proliferative potential, and the inability to form a new tumor. Only the CSC is able to initiate tumor formation as it is solely capable of self-renewal (Figure 1). CSCs are thought to maintain their numbers by slow selfreplication and produce other tumor cells by asymmetric cell division. In this process, cell division of a CSC generates a CSC and a transformed "progenitor-like" cell, which has limited self-renewal ability but is highly proliferative, similar to a transit-amplifying 


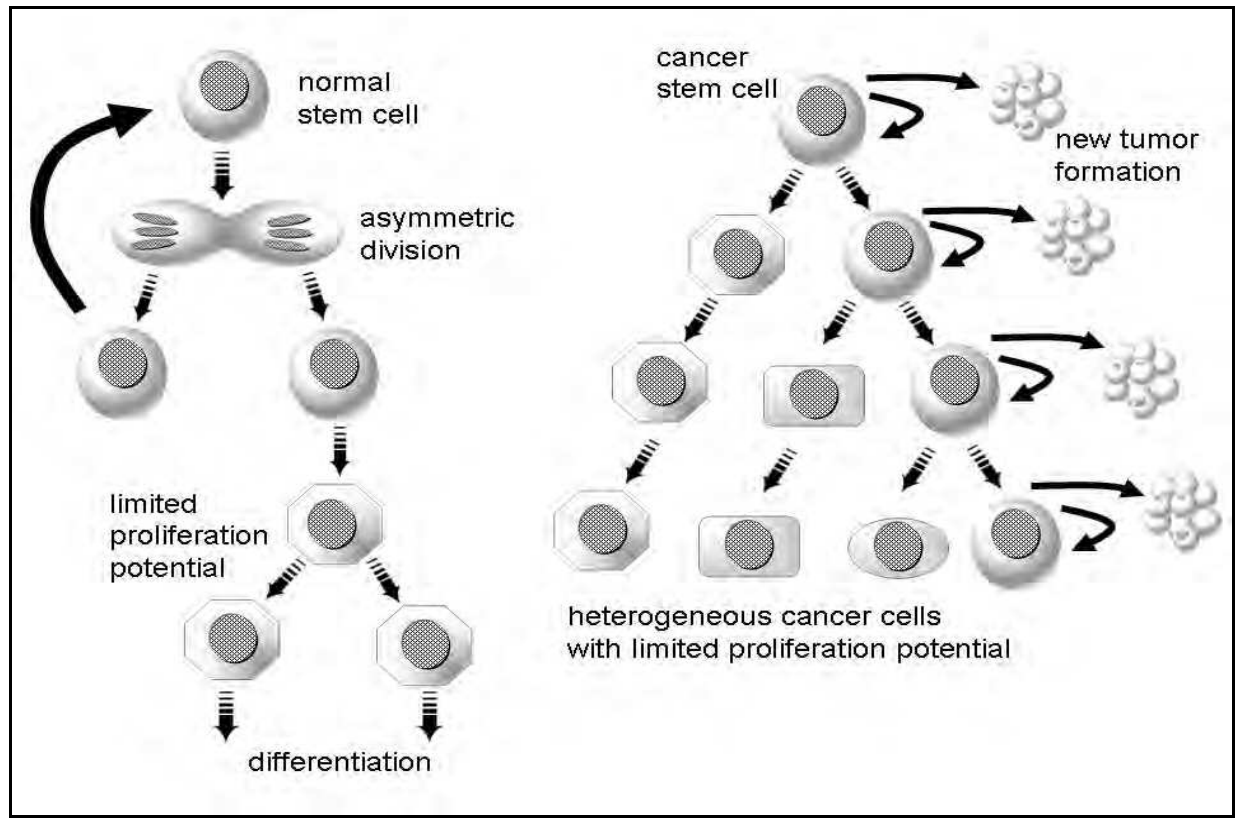

Fig. 1. The cancer stem cell hypothesis. In normal tissues, cell numbers are regulated by asymmetric division of stem cells to replace the loss of functional differentiated cells. In cancer, the mutated stem cell drives tumor heterogeneity through asymmetric division and aberrant proliferation/differentiation. Only the CSC has the capacity to form new tumors and accumulate further mutations leading to tumor progression.

population in normal tissues. These progenitors give rise to more or less partially differentiated bulk tumor cells through a combination of proliferation and abortive differentiation.

The existence of CSCs has been supported by seminal research performed on acute myeloid leukemia (AML), where it has been demonstrated that only a specific cellular subset that express antigenic markers similar to hematopoietic stem cells has clonogenic activity in immunocompromised mice (Lapidot et al. 1994; Bonnet and Dick 1997). The cell responsible for tumor initiation was identified as having a $\mathrm{CD} 34^{+} \mathrm{CD} 38^{-}$phenotype; interestingly the majority of AML cells tend to be CD34-. It was observed that as few as $5 \times 10^{3} \mathrm{CD}^{-} 4^{+} \mathrm{CD} 38^{-}$ cells could successfully engraft an immunocompromised mouse, while 100 times more $\mathrm{CD} 4^{-}$or CD34+ ${ }^{+} \mathrm{CD} 38^{+}$cells were not tumorigenic (Bonnet and Dick 1997). Significantly, the resulting tumors were heterogeneous and composed of a mixture of tumorigenic and nontumorigenic cells similar to the donor leukemia. Subsequently, studies on tumors of epithelial origin, such as breast cancer, also provided evidence for the presence of stem-like cells within the cancer (Dontu et al. 2005). Ponti and colleagues demonstrated that only $\mathrm{CD}_{4}{ }^{+} / \mathrm{CD} 24-$ cells, isolated from breast cancer, were able to produce tumors in immunocompromised mice (Ponti et al. 2005). The initial publications in leukemia and breast cancer were followed by reports showing the prospective isolation of CSCs in numerous malignancies including: brain, colon, head and neck, pancreatic, melanoma, mesenchymal, hepatic, lung, prostate, and ovarian tumors (O'Brien et al. 2010). The 
existence of CSCs in rectal cancer has yet to be verified by stem cell isolation and xenotransplantation into immunodeficient mice.

\section{Intestinal structure and the stem cell niche}

The large bowel consists of a rapidly proliferating and perpetually differentiating epithelium. Unlike the small intestine, the mucosal surface of the colon has no villi. The ileocecal junction marks an abrupt transition from the villi of the small intestine to the smooth glandular pattern of colon. The crypts of Leiberkuhn continue, and these straight tubular glands are lined with simple columnar epithelium for the reabsorbtion of water and electrolytes, numerous goblet cells for mucus secretion, stem cells for replication, and occasional enteroendocrine cells. Stem cells located in the crypts of Lieberkuhn give rise to proliferating progenitor or transit amplifying cells that differentiate into the four major epithelial cell types (Figure 2). These include columnar absorptive cells or enterocytes, mucous-secreting goblet cells, enteroendocrine cells, and Paneth cells. Enterocytic, goblet, and enteroendocrine cell differentiation takes place during migration upward from the crypt to the surface epithelium, whereas Paneth cells complete their differentiation at the crypt base. The crypt is surrounded by the supporting lamina propria which contains cells of mesenchymal origin, the pericryptal myofibroblasts, which are derived from a mesenchymal lineage.

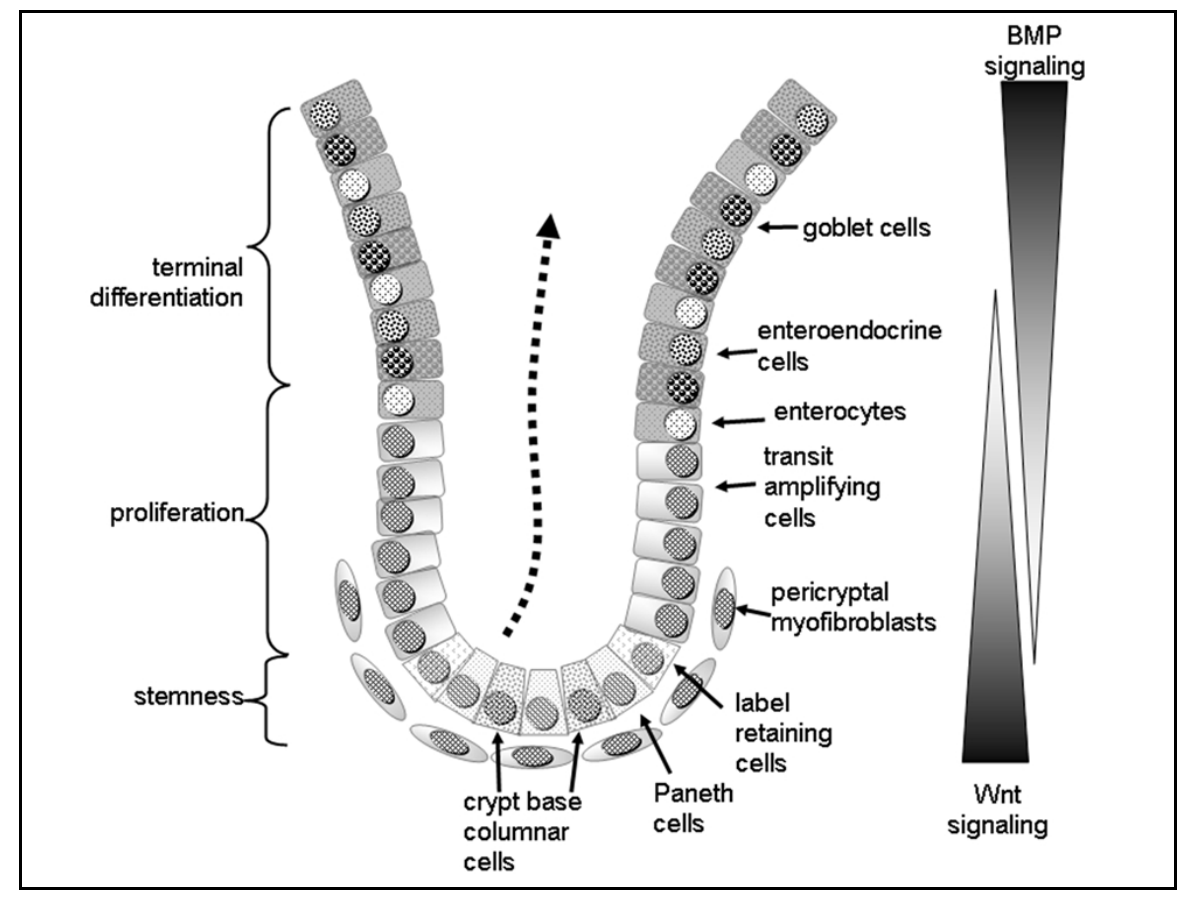

Fig. 2. The intestinal stem cell structure. Two putative populations of stem cells exist: (1) a quiescent/reserved population that consists of label retaining cells located above the basally situated Paneth cell and (2) an actively cycling/primed population that consists of crypt base columnar cells. 
Much of the detailed research on intestinal stem cells has been carried out in the setting of the small intestine where the localization of putative intestinal stem cells (ISCs) was initially studied using indirect means. Based on the premise that stem cells may be slowly cycling, Potten and colleagues used long-term label retaining techniques (tritiated thymidine or bromodeoxyuridine) to mark putative ISCs in the small intestine (Potten et al. 1997). They detected long-term label-retaining cells (LRCs) in an annulus four cells up (+4 LRCs) from the crypt base. More recently, using in vivo lineage tracing, it was shown that cells expressing BMI1 predominantly mark +4 LRC position and are able to give rise to all four epithelial lineages (Sangiorgi and Capecchi 2009). BMI1 encodes a chromatin remodeling protein of the polycomb group that has essential roles in self-renewal of hematopoietic and neural stem cells. However, an alternative hypothesis was put forward by Barker and colleagues, who identified a WNT target gene, LGR5/GPR49, which is expressed exclusively in crypt base columnar cells (CBCs) at crypt positions 1-4 (Barker et al. 2007). They elegantly showed that LGR5- expressing CBCs fulfill all criteria of putative ISCs in that they can persist for a long time, self-renew, give rise to all mature intestinal epithelial cells, and are also apoptosis-resistant. However, in contrast to the putative +4 LRC/BMI1 cells, they are highly proliferative. This raises the possibility that there are two types of intestinal stem cells: quiescent stem cells +4 LRC/BMI1 reflecting their inhibitory microenvironment, and the active CBC/LGR5-positive stem cells, representing a population of stem cells able to respond to stimulating signals generated from adjacent mesenchymal cells (Scoville et al. 2008). Very recently, work from Clevers laboratory has implicated the Paneth cell as an important component of the CBC/LGR5 niche (Sato et al. 2011).

There are clear differences between the small and large intestine, apart from the lack of villi. Paneth cells are not generated in the large intestine, and there are differences in the enteroendocrine cell types. However, colonic stem cells have also been shown to reside in the base of the crypts within the stem-cell niche, which is formed by the stem cells themselves and mesenchymal cells that surround the crypt base (Potten 1998). Using bromodeoxyuridine injections into patients with various colorectal cancers, we were able to show marked differences in the proliferation characteristics of "normal" ileum, colon and rectal mucosa (Potten et al. 1992). The mean crypt height in sections of the human colon was 81.9 and 79.5 cells for the rectum. The mean crypt circumference was 41.6 cells in the colon, and 46.0 cells in the rectum. This gave a total of 2044 cells per crypt in the colon and 2194 cells per crypt in the rectum. In the colonic crypts $10 \%$ of cells were in S phase and $04 \%$ in mitosis. Ninety per cent of labeled cells were found between cell positions 4 and 43; we showed that the maximum labeling index was about $30 \%$ and occurred at cell position 15 . The labeling index at the crypt base, the putative stem cell zone, was about $14 \%$. The rectum showed significant differences. The rectal mucosal crypts contain approximately $30 \%$ fewer $S$ phase and mitotic cells (Figure 3). This may indicate either that the cell cycle time of rectal mucosa cells is longer than in the colon, or that there are fewer proliferating cells in the rectum. Extrapolating from biologic studies in rodents suggests that ISCs in the human colonic and rectal crypts represent only a small proportion of crypt cells (approximately 20 cells per crypt, or approximately 1\%) (Potten and Loeffler 1990). This finding is consistent with recent immunostaining studies in human colonic crypts for Musashi-1 protein, a putative ISC marker, indicating that there are, on average, 19 ISCs per crypt (Potten et al. 2003).

A key component of tissue architecture that is involved in the regulation of stem cells has been termed the "stem cell niche " (Spradling et al. 2001). The stem cell niche has been well characterized in hematopoietic and neural systems and is an intricate and dynamic milieu 


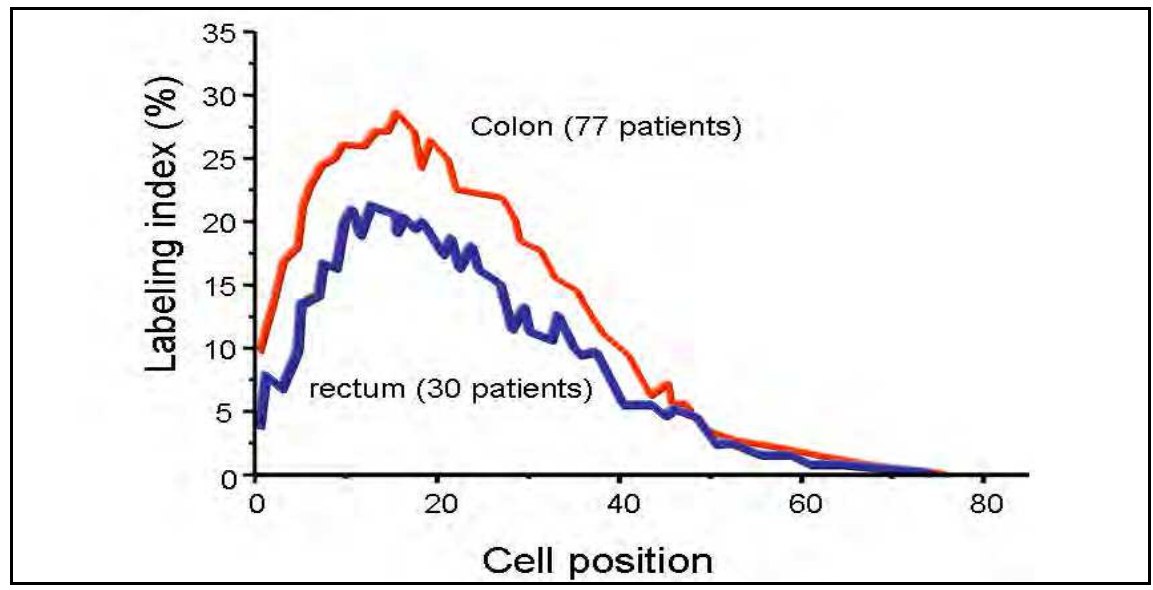

Fig. 3. A comparison of the bromodeoxyuridine labeling index frequency plots for the human colon and the rectum.

that adapts in response to environmental signals. The niche consists of a stromal microenvironment surrounding the stem cell population that can contain neural cells, lymphocytes, macrophages, endothelial cells, fibroblasts, smooth muscle cells and myofibroblasts in an extracellular matrix ( $\mathrm{Li}$ and Xie 2005). As mentioned previously, the crypt is surrounded by the supporting lamina propria which contains pericryptal myofibroblasts. These myofibroblasts are thought to be strategic cells in the regulation of stem cell behavior through growth factor and cytokine signaling (Mills and Gordon 2001). Several key signaling pathways are common to stem cells and their niche including Wnt, BMP and Notch.

The discovery that mutations in the APC gene, the most important tumor suppressor in intestinal tumorigenesis, affects the control of Wnt signaling, indicated the importance of this pathway in intestinal stem cell regulation (Korinek et al. 1997). It is thought that the pericryptal myofibroblasts produce the Wnt signaling ligands that access Frizzled receptors on the basal epithelial stem cells (Fevr et al. 2007), and this prevents degradation of the main effector, $\beta$-catenin by a destruction complex containing APC and AXIN1/2. $\beta$-Catenin translocates to the nucleus, where it acts as a transcriptional activator after binding to TCF/LEF family members. Korinek et al showed that lack of the intestine specific $\beta$-catenin partner, TCF4, resulted in the depletion of the epithelial stem cell compartment in the small intestine (Korinek et al. 1998). Wnt signaling varies across the crypt (Kosinski et al. 2007) in that the crypt top is characterized by APC, WNT5B, and TCF4 whilst the crypt bottom, the putative stem cell niche, expresses AXIN2, TCF3, and several secreted Wnt inhibitors including DKK3, SFRP1, SFRP2, FZD2, FZD3, FZD7, and FZDB. The identification of many different Wnt/ $\beta$-catenin target genes indicates that Wnt signaling has different effects in different cell types depending on their localization along the crypt axis. The microenvironment surrounding the LGR5/GPR49 stem cell is characterized by prominent Wnt activity and inhibition of BMP signaling with the presence of BMP inhibitors noggin and gremlin whereas the microenvironment surrounding the +4 LRC is characterized by expression of the Wnt inhibitor sFRP5 and BMP4 (Pages et al. 2009). 
This also highlights the importance of members of the BMP pathway as important contributors to the colorectal epithelial stem cell niche by modulation of the Wnt pathway. Bone morphogenetic proteins (BMPs) bind to BMP receptor types I or II (BMPR1 or BMPR2) leading to phosphorylation of SMAD1, 5 or 8, which then form a heterodimer with SMAD4, translocate to the nucleus, and act as transcriptional activators (von Bubnoff and Cho 2001). Active BMP signaling, indicated by phosphorylated SMADs, is found predominantly in differentiated intestinal epithelial cells. Several lines of evidence support the postulated inhibitory role of BMP signaling on stem cell self-renewal. These include the observations that conditional mutation of BMPR1A resulted in de novo crypt formation and a juvenile polyposis phenotype (He et al. 2004) and leads to reduced differentiation into the three secretory cells types, Paneth cells, goblet cells and enteroendocrine cells in mice (Auclair et al. 2007). Also, human juvenile polyposis has been shown to be associated with mutations in the SMAD4/DPC4 or BMPR1A genes (Sayed et al. 2002).

Several other pathways have been shown to be important in intestinal stem cell regulation including Notch signaling, hedgehog signaling, and the PTEN-PI3K-Akt pathway. Notch has been implicated in the control of cell fate in many tissues. The binding of the ligands Jagged or Delta to the Notch receptor induces proteolytic cleavage by $\gamma$-secretase which releases a fragment, NCID. This fragment translocates to the nucleus and acts as a transcription factor after dimerization with RBP-j $\kappa / C S L$. One of the key genes stimulated by this activation is a bHLH transcription factor termed hairy/enhancer of split (Hes), which has been shown to activate factors involved in the control of proliferation and differentiation (Bray 2006). Knocking out RBP-j $\kappa$ or Hes1 leads to increased numbers of secretory epithelial cells (Jensen et al. 2000) whereas mutation in ATOK1, a transcription factor repressed by Notch signaling, leads to depletion of all three secretory lineages (Yang et al. 2001). Therefore, Notch functions by stimulating proliferation of crypt progenitor cells in the transit-amplifying units, and suppression of Notch signaling induces specific differentiation into the intestinal epithelial lineages. A role of the PTEN-PI3K-Akt in enhancing stem cell self-renewal in the intestine has been suggested as a result of the connection between this pathway and the Wnt pathway. p-Akt can phosphorylate $\beta$-catenin and thus enhance the transcriptional activity of $\beta$-catenin whilst PTEN exhibits strongest expression in lumenal epithelial cells and might be involved in the restriction of strong Wnt signaling to the crypt base (Persad et al. 2001). In contrast to the other signal pathways which seem to be regulated in response to ligands originating from the niche cells, the morphogens of the hedgehog (HH) pathway, sonic hedgehog (Shh), and Indian hedgehog (Ihh) are secreted by epithelial cells. Their receptor, Patched (PTCH), is expressed on the pericryptal myofibroblasts. Accordingly, $\mathrm{HH}$ signaling is not directly concerned with the fate of the epithelial cells but is important in shaping and regulating the proper overall structure of the intestinal mucosa into crypts and villi (Madison et al. 2005).

\section{Stem cells and the development of colorectal cancer}

The mechanisms underlying colorectal cancer initiation have yet to be fully elucidated (see section 5). It is clear that the APC gene is involved as APC mutations are found in $75 \%$ to $80 \%$ of sporadic CRCs (Powell et al. 1992). However, mutations in mitochondrial DNA and mutations in the genes encoding cytochrome c oxidase (COX), a component of complex IV of the respiratory chain, are also relatively common (Taylor et al. 2003). 
When an initial mutation occurs in a basally situated crypt stem cell, it gives rise to a clone that migrates up the crypt, expanding as it progresses. At this stage the proliferation pattern of crypts are shifted toward the crypt top with a maximum labeling index (LI) at approximately crypt level 20 . The mutant clone then begins to colonize the base of the crypt, in effect taking over and replacing the non-mutant cells in the stem-cell niche in a process that has been termed niche succession. Eventually the entire niche will be colonized with mutant stem cells and the crypt filled with their progeny, a result termed monoclonal conversion. Interestingly, crypts containing this proliferative abnormality do not show any discernible histological changes. Crypts only begin to show obvious abnormalities when they become dysplastic during later formation of premalignant adenomas. Boman and colleagues have postulated that only an increase in crypt SC number and not changes in cell cycle proliferation, differentiation, or apoptosis of non-SC populations, could explain the LI shift in these crypts (Boman et al. 2001). This led to the hypothesis that the link between APC mutation and the LI shift is crypt SC overpopulation caused by a decrease in the rate of degradation of cytoplasmic $\beta$-catenin and alteration of TCF-4 transcriptional activity and survivin expression leading to inhibition of apoptosis and promotion of mitosis (Boman and Huang 2008).

Inactivation of the second APC allele occurs during the development of intestinal adenomas, and it has been proposed that the next critical event may be the movement of the progeny of the mutated stem cell moving from the niche into the proliferative zone of the crypt where they are freed from the constraints of the niche cells and are able to undergo further symmetric divisions and clonal expansion forming monocryptal adenomas (Humphries and Wright 2008). These are the earliest histologically detectable precursor lesions of tumor development and are thought to precede adenoma development. Further clonal expansion seems to be through crypt fission. Crypt fission is a normal process that leads to crypt replication. This process is responsible for the increased number of new crypts that arise during a short postnatal period, after which the total number of crypts increases only gradually with age. During crypt fission, development of a fissure bisects the crypt base and ascends longitudinally. This bifurcation results in the symmetric creation of two identical daughter crypts and must therefore be a process that results from symmetric ISC division. Experimental evidence suggests that mutant APC and an increasing rate of crypt fission, leads to abnormal, asymmetric crypt fissioning during adenoma development resulting in characteristic crypt branching and budding (Wasan et al. 1998). Crypt fission is also the mechanism that leads to the spread of mutant crypt populations in normal colonic epithelium. Further development of the lesion may be through random collision between neighboring neoplastic clones or through clonal interaction in which active cooperation between multiple initiated clones promotes continued survival and growth of the adenoma leading to genetic heterogeneity (Axelrod et al. 2006). Indeed, it has been shown that genetic alterations occur in the stroma from an early stage of carcinogenesis and that these may induce microregional differences in tumor susceptibility promoting loss of heterozygosity in the associated epithelium (Thliveris et al. 2005).

\section{Genetic differences between colon and rectal tumors}

The most well known model for colorectal carcinogenesis (the Vogelstein model) describes the progression of normal epithelium into adenomatous polyps and neoplasia and finally into metastatic carcinoma (Fearon and Vogelstein 1990). A series of specific genetic 
alterations are responsible for the transition to more tumorigenic phenotypes. While alterations in the APC (adenomatous polyposis coli gene)/ $\beta$-catenin pathways as well as inactivation of mismatch repair proteins generally occur early, modifications to p53 and DCC/SMAD4/SMAD2 occur as one of the final steps in the progression to carcinoma. The step-wise progression of colorectal carcinogenesis through transitional dysplastic and adenoma stages is demonstrated by the high rate of success seen in preventing the development of colorectal cancer by removing polyps. Polyps represent the dysplastic and adenoma stages of colorectal carcinogenesis, and their removal prevents the development of carcinoma.

There are three main pathways that lead to the genetic alterations responsible for colorectal tumorigenesis, the chromosomal instability (CIN) pathway, the mismatch repair (MMR) pathway and the hypermethylation phenotype. The CIN pathway is characterized by alteration of APC tumor suppressor gene signaling. A germline mutation of the APC gene results in the development of familial adenomatous polyposis (FAP) which is typified by hundreds to thousands of colorectal polyps by age 20-30. Tumors that developed via the CIN pathway have a high level of chromosomal instability that results in large numbers of deletions, insertions, and loss of heterozygosity. The MMR pathway to colorectal carcinogenesis results from a failure of DNA repair genes, in particular MLH1 and MSH2. This malfunction in DNA repair results in an accumulation of errors throughout the genome, particularly in areas called microsatellites. Microsatellites are short nucleotide regions that are repeated hundreds of times within the genome; thus, the MMR pathway is characterized by microsatellite instability. Germline mutations in one of the MMR genes results in hereditary nonpolyposis colorectal cancer (HNPCC). Finally, the hypermethylation pathway is characterized by a high incidence of methylation of CpG islands which may result in gene silencing of the MMR genes.

In addition to these major pathways in colorectal carcinogenesis, there are specific genetic pathways that have a role in colorectal carcinogenesis. The gene K-ras is mutated in $\sim 50 \%$ of sporadic colorectal cancer and in $50 \%$ of adenomas larger than $1 \mathrm{~cm}$ while rarely in smaller adenomas (Vogelstein et al. 1988). The lack of mutations in the smaller adenomas implies that the K-ras mutation is relevant to a later stage of progression. However, the presence of K-ras mutations in both nondysplastic aberrant crypt foci and hyperplastic polyps makes the role of these mutations unclear.

Another commonly mutated gene in colorectal cancer is p53. In response to DNA damage and other stress, p53 induces responses ranging from cell cycle arrest and senescence to differentiation and is inactivated in $50-70 \%$ of colorectal cancers. The p53 gene is located on chromosome $17 \mathrm{p}$ which is lost in up to $75 \%$ of colorectal cancers, but it is lost rarely in adenomas. This suggests that the loss occurs late in the progression (Baker et al. 1990).

One more common feature of colorectal cancers is the loss of chromosome 18q. The deletion is seen in $73 \%$ of sporadic colorectal cancers and $47 \%$ of large adenomas but less in smaller adenomas (Vogelstein et al. 1988). This divergence implies the chromosomal loss occurs later in tumorigenesis. Chromosome 18q contains three significant genes: DCC ("deleted in colon cancer"), SMAD4, and SMAD2. DCC functions as a tumor suppressor and has a role in cell-cell interactions. Loss of DCC expression is associated with a worse overall survival in colorectal cancer patients (Popat et al. 2007). As mentioned previously, SMAD4 and SMAD2 are both involved in BMP signaling as well as in the TGF $\beta$ signaling cascade which modulates cell proliferation, apoptosis, and differentiation. 
However, while cancers of the colon and rectum have generally been grouped into the single category of "colorectal" cancer, it has long been speculated that cancers that develop in different anatomical areas of the colon and rectum should be considered as separate diseases. Differences in the biology and function and risk factors between proximal colon, distal colon, and rectum may lend to these divergent disease entities. Genetic evidence also supports etiological evidence that colon and rectal tumors are different entities. These differences between colon and rectal tumors include incidence of certain gene mutations, change in gene expression, even differences in the mechanisms of carcinogenesis. The frequency of mutations to K-ras and APC differs between sites. Mutations to K-ras were more widespread in tumors of the colon. Rectal cancer more often has mutations restricted to APC while colon cancers often contain mutations in several genes (Frattini et al. 2004). In fact, the number of genetic mutations regardless of gene were higher in colon than the rectum (Li and Lai 2009).

In addition to mutations, there are several genes that show different levels of expression between rectal and colon cancers including $\beta$-catenin, MMR proteins, p53, and COX2 (cyclooxygenase 2). $\beta$-catenin binds the APC protein and is involved in regulating cell growth and adhesion between cells. The cellular localization of $\beta$-catenin is altered between colon and rectal cancers. Nuclear $\beta$-catenin expression was found more often in cancers of the rectum than colon (Kapiteijn et al. 2001), and reduced membranous and cytoplasmic staining was associated with increased metastatic disease in rectal cancer (Fernebro et al. 2004). Unlike colon cancer, rectal tumors rarely show a loss of expression in MMR proteins including MLH1 and MSH2 (Fernebro et al. 2004). Over-expression of p53 was more common in rectal cancers than colon cancer; however, this may indicate a higher level of p53 mutation in rectal cancer (Kapiteijn et al. 2001). In addition, $90 \%$ of rectal tumors demonstrate up-regulation of COX2 while only $20 \%$ of colon cancers had increased levels (Li and Lai 2009).

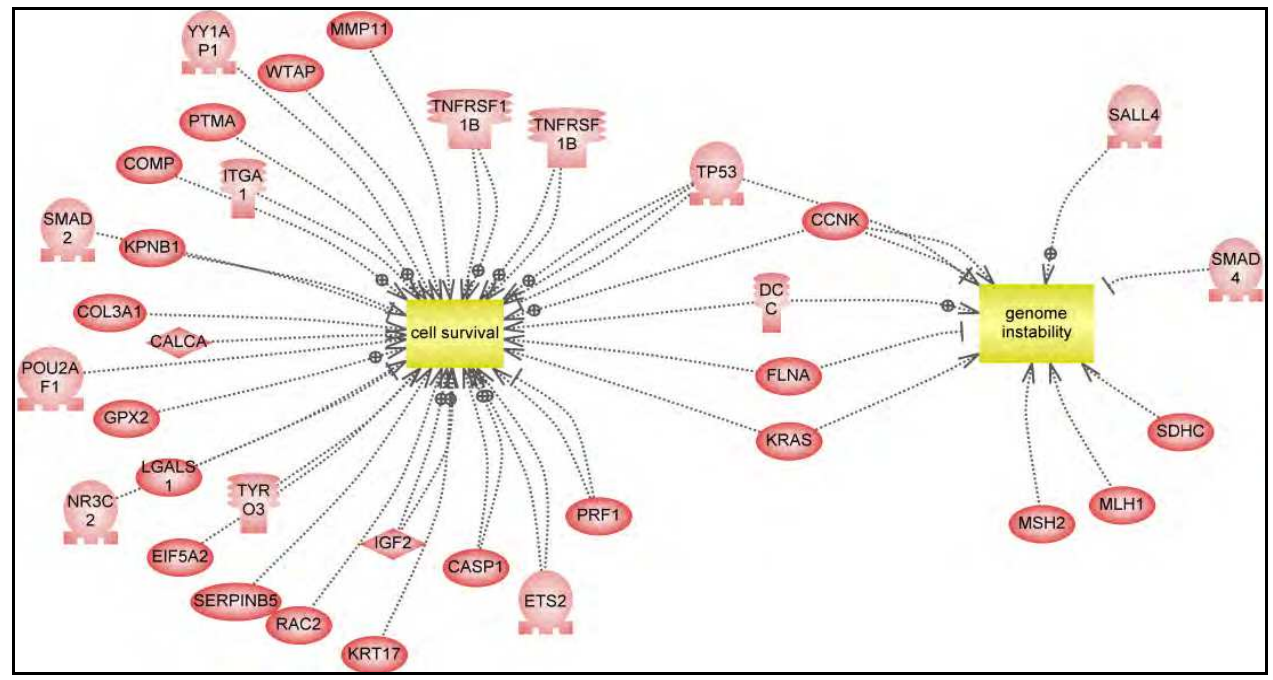

Fig. 4. Gene expression linked cell survival and genome instability in rectal cancer. Genes identified in 4 gene expression studies of rectal cancer were highly represented by genes involved in cell survival and genome instability. Pathway generated by Ariadne Pathway Studio. 
These differences in mutational and gene expression patterns demonstrate a fundamental difference in the carcinogenesis of rectal and colon cancer. With the low rate of MMR disruption seen in rectal cancer, the incidence of MSI is quite low. However, the incidence of $\mathrm{CIN}$ is high in rectal cancer as exemplified by the mutations seen in APC. The importance of genomic instability in rectal cancer is further illustrated by examining gene expression studies which were done to differentiate rectal cancer patients that respond to radiation therapy (Watanabe et al. 2006; Ojima et al. 2007; Rimkus et al. 2008) or patients that have local recurrence (Kalady et al. 2010). These four studies identify a total of 120 genes that are differentially expressed between rectal cancer patient populations. Of these genes, 30 are associated with cell survival, and 10 have been linked to genome instability (Figure 4).

\section{Current candidates as stem markers in rectal tumors}

Various cell surface markers (Table 1) have been used for the identification of cancer stem cells. These markers are used to isolate sub-populations of cells that are characterized by the ability to reconstitute the original tumor by xenotransplantation using a limited number of cells. Breast cancer stem cells that are CD44 ${ }^{+} \mathrm{CD} 24-/$ low $\mathrm{Lin}^{-}$are able to form tumors in mice using as few as 100 cells while injection of tens of thousands of cells with different phenotypes fail to form tumors (Al-Hajj et al. 2003). Similarly, CD133+ cells from brain tumors are able to form tumors with an original xenograft of only 100 cells (Singh et al. 2004). Even more astonishing, human ovarian cancer cells that have high ALDH activity and express the cell surface marker CD133 are able to form tumors in mice using as few as 11 cells (Silva et al. 2011).

\begin{tabular}{|c|c|}
\hline Site & Markers \\
\hline $\begin{array}{l}\text { Brain / } \\
\text { CNS }\end{array}$ & $\mathrm{CD}^{2} 33^{+}$(Singh et al. 2004), ALDH1 activity (Wang et al. 2011) \\
\hline Breast & CD44+ CD24-/low Lin- (Al-Hajj et al. 2003), ALD1 activity (Marcato et al. 2011) \\
\hline Esophagus & Hoescht exclusion (Kalabis et al., 2008) \\
\hline HNSCC & $\begin{array}{l}\text { CD44+ (Harper et al. 2007), CD133+ (Yang et al. 2011), ALDH activity } \\
\text { (Clay et al. 2010), Hoescht exclusion (Sun et al. 2010) }\end{array}$ \\
\hline Lung & CD133+ (Bertolini et al. 2009), ALDH activity (Liang and Shi 2011) \\
\hline Melanoma & CD20+ (Zabierowski and Herlyn 2008), CD133+ (Gazzaniga et al. 2010) \\
\hline Ovary & ALDH activity (Silva et al. 2011), Hoescht exclusion (Hosonuma et al. 2011) \\
\hline Pancreas & $\mathrm{CD}_{4}{ }^{+} \mathrm{CD} 24^{+} \mathrm{ESA}^{+}$(Lee et al. 2008), ALDH activity (Kim et al. 2011) \\
\hline Prostate & $\mathrm{CD}_{4} 4^{+}$a2 $\beta 1^{\text {high }} \mathrm{CD} 133^{+}$(Miki et al. 2007) \\
\hline Colon & $\begin{array}{l}\text { CD44+ ESA high (Dalerba et al. 2007), CD133+ (Ricci-Vitiani et al. 2010), CD166 } \\
\text { (Dalerba et al. 2007), ALDH activity (Huang et al. 2009), Lgr5've (Takahashi et } \\
\text { al. 2011) }\end{array}$ \\
\hline Rectum & $\begin{array}{l}\text { CD } 44^{+} \text {(Nagata et al. 2011), CD133+ (Nagata et al. 2011), CD133+ESA }{ }^{+} \text {(Yang et } \\
\text { al. 2010) }\end{array}$ \\
\hline
\end{tabular}

Table 1. Stem cell markers. CNS: central nervous system; HNSCC: Head and neck squamous cell carcinoma; ALDH: aldehyde dehydrogenase-1; ESA: epithelial-specific antigen 
As mentioned previously, there are several critical pathways that are involved in the maintenance of cancer stem cells including the Wnt, Sonic Hedgehog (SHH), Notch, phosphoinosital-3-kinase (PI3K), and bone morphogenic protein (BMP) pathways (Brabletz et al. 2009). Interestingly, most of the known cancer stem cell markers are not directly related to these pathways; however, these signaling pathways are up-regulated in these cancer stem cell-enriched sub-populations. Pancreatic cancer stem cells that are CD44+ CD24+ ESA+ show an up-regulation of SHH and BMI-1 signaling. These pancreatic cancer stem cells represent less than 1\% of all pancreatic cancer cells (Lee et al. 2008), and 100 of these pancreatic stem cells are able to form tumors that are indistinguishable from the original tumor (Chen et al. 2011).

In colorectal cancer, $\mathrm{ALDH}^{+}$cells are rare in the normal colorectal epithelium and located exclusively in the normal crypt base which is the proposed location for colorectal stem cells. As colorectal carcinogenesis progresses from normal through adenoma and carcinoma, the number of ALDH+ cells increases as well as being distributed more extensively (Huang et al. 2009). Colorectal tumor cells that express both CD44 and ESA are able produce tumors and reproduce the full heterogeneity of the original tissue. CD133+ colorectal cancer stem cells constitute $2.5 \%$ of all cells in the tumor (Ricci-Vitiani et al. 2010). These CD133+ cells are able to reproduce the original tumor while the CD133- cells cannot form tumors. However, it is worth noting that a study using fractionating dilution revealed that 1 in 262 CD133+ cells are able to form tumors (O'Brien et al. 2007). While significantly enriched compared to the unfractionated cell population which form tumors at a rate of 1 in 57,000, it still illustrates that not all $\mathrm{CD} 133^{+}$cells are able to reconstitute the original tumors.

Although CSCs have been studied in colon cancer, the existence and implication of stem cells has not been extensively studied in rectal cancer. In a case study, Yang et. al. found elevated levels of CD133+ ESA+ cancer stem cells circulating in the blood of a 75-year old rectal cancer patient who later developed liver metastasis (Yang et al. 2010). Immunohistological analysis of rectal cancer tissue demonstrated that local recurrence was greater for patients that were positive for either CD133 or CD44 (Nagata et al. 2011). Yasuda and colleagues (Yasuda et al. 2009) showed that elevated CD133, but not VEGF or EGFR, was a predictive marker of distant recurrence after preoperative chemoradiotherapy in rectal cancer while Wang et. al. (Wang et al. 2009) showed that the proportion of CD133+ cells was a significant prognostic factor for adverse disease-free survival and overall survival independent of TNM stage, tumour differentiation or lymphovascular invasion. More recently, Kojima and colleagues (Kojima et al. 2010) studied 92 cases of rectal cancer of which 43 patients received preoperative chemoradiation therapy and 49 patients underwent surgery alone. Forty pretreatment biopsy specimens from 43 patients in the preoperative chemoradiation therapy group were also analyzed. CD133-positive cases were more common in the preoperative chemoradiation therapy group than in the surgery-alone group. Furthermore, CD133-positive cases were more common in the preoperative chemoradiation therapy group than in pretreatment biopsy specimens. In the preoperative chemoradiation therapy group, the CD133-positive cases showed poorer prognosis than the CD133-negative cases. These studies suggest that the CD133+ population is important for outcome and that chemoradiation enriches this population.

The biological function of CD133 remains unknown. It is a transmembrane pentaspan protein that was initially described as a surface antigen which was specific to human hematopoietic stem cells (Yin et al. 1997). Utilizing the literature mining software found in Ariadne Pathway Studio, Figure 5 illustrates the known relationships found between CD133 
and other genes and cellular processes. Cellular processes that are associated with CD133 include those that are expected to be involved with cancer stem cells: cell death, morphogenesis, apoptosis, cell differentiation, cell proliferation, and drug response (response to drug). Others may provide hints at important processes that have yet to be investigated: lipid metabolism, glucose metabolism, and vascularization. In addition, CD133 is linked with well-known cancer-related genes such as p53, Myc, Src, and transforming growth factor $\beta 1$ and the TGF $\beta$-associated SMAD6 and SMAD7. Expression of the gene HIF$1 \alpha$ in conjunction with CD133 is associated with tumor recurrence following chemoradiation (Saigusa et al. 2011). Also associated with recurrence of rectal cancer after chemoradiation is putative stem cell marker POU class 5 homeobox 1 (POU5F1). Expression of CD133, POU5F1, and the SOX2 gene following treatment was associated with poor disease-free survival.

The addition of other known cancer stem cell markers such as CD44 and ESA (EPCAM) to the diagram exemplifies the level of similarity in signaling. Figure 5 shows CD133 associated with 61 other genes and cellular processes. While ESA is associated with 10 of these entities, CD44 has been linked with almost half. CD44 has been associated with the inhibition of apoptosis, cell differentiation, and p53 signaling/expression. Both CD133 and CD44 are linked to CXCL12 (chemokine (C-X-C motif) ligand 12). CXCL12 and its receptor CXCR4 have previously been associated with the mobilization and homing of hematopoetic stem cells (Juarez and Bendall 2004). Interestingly, CXCR4 overlaps much of the CD133 signaling and has been implicated in cancer stem cell signaling at several other sites. Sustained CXCR4/CXCL12 signaling occurs in prostate cancer stem cells (Mimeault and Batra 2011) and is involved in the up-regulation of stem cell-related gene expression in breast cancer cells (Zhang et al. 2011). Additionally, CXCR4 was identified as a therapeutic target of glioblastoma stem cell-like cell lines (Schulte et al. 2011). This implies that, while many markers may be used to identify cancer stem cells, much of the signaling behind these superficial membrane markers may be quite similar.

\section{Stem cells and treatment response}

The mainline cancer therapies of conventional chemo- and radiotherapy target rapidly cycling cancer cells and can cause impressive, but usually temporary, clinical remissions. This initial remission followed by local recurrence would support the argument for the existence of a small subpopulation of resistant CSCs, while at the same time the majority of the non-CSCs being responsive to the treatment. Treatment failure could be explained by several CSC characteristics that would make them difficult to eradicate by conventional agents. First, they may be slow-cycling or quiescent rendering them less sensitive to agents that target actively cycling cells. Second, a characteristic of many normal stem cells is the increased activity of $\mathrm{ABC}$ transporter proteins as a protective mechanism against environmental toxins; these are also up-regulated in CSCs (Dean et al. 2005). Third, there are data suggesting that CSCs may be more resistant to radiation (Bao et al. 2006) although this has not been universally found (McCord et al. 2009).

CD133 has been extensively studied in the context of radiation sensitivity in the setting of glioma. An increase of the CD133+ fraction following irradiation of human glioma cells has been shown in vitro as well as in tumors in nude mice (Bao et al. 2006). The CD133+ cell fraction was found to have a reduced sensitivity to radiation-induced apoptosis. Interestingly, when CD133+ cells were irradiated with 3Gy, they were able to initiate tumors 


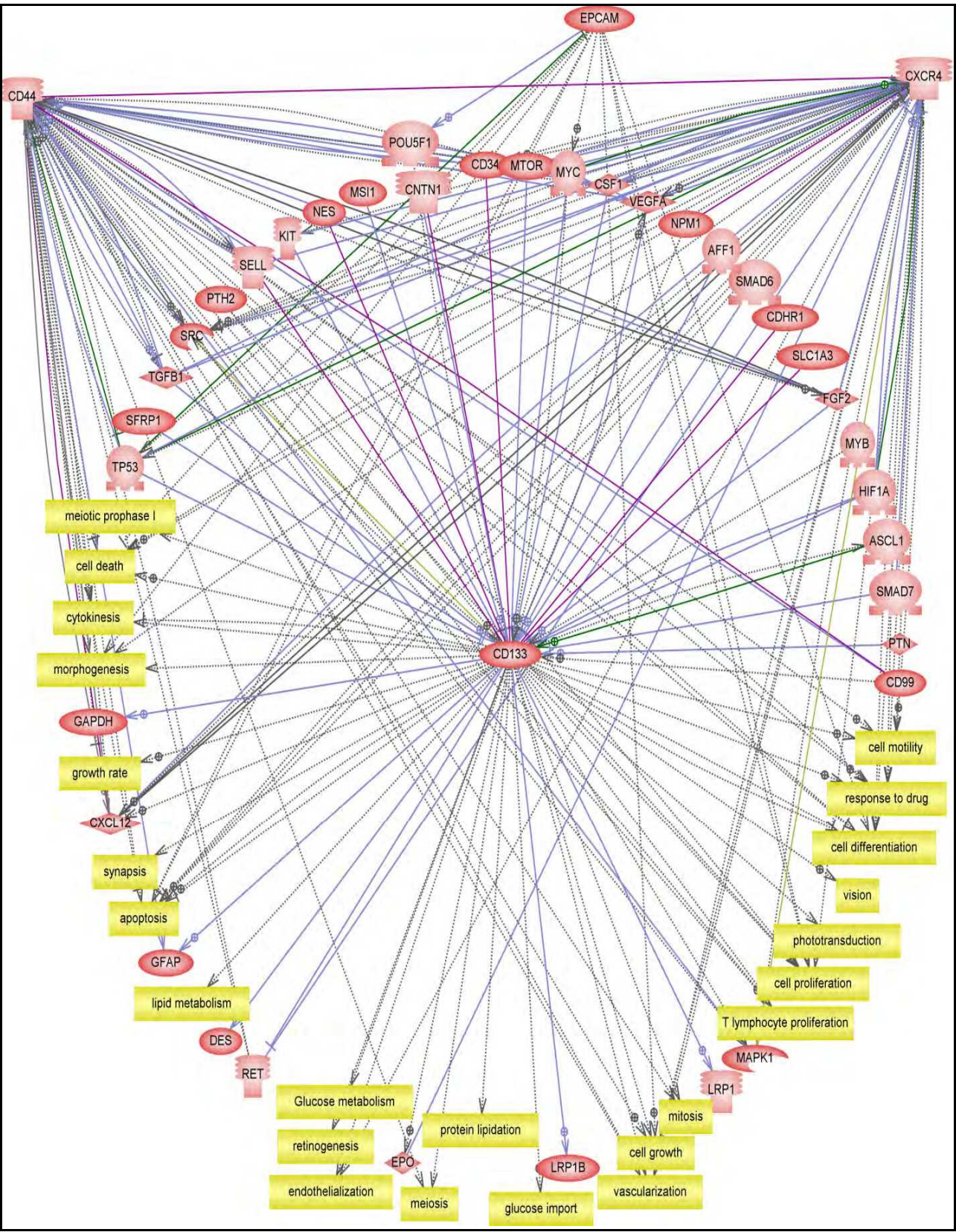

Fig. 5. Genes and cellular processes associated with CD133 expression. The literature mining software in Ariadne Pathway Studio software identifies genes and cellular processes that have been shown to be associated with CD133. This figure was supplemented by adding the stem cell markers CD44, ESA (EPCAM), and CXCR4. 
with almost the same efficacy than the non-irradiated CD133+ cells. A clinical study in atypical teratoid/rhabdoid tumors demonstrated a correlation of the amount of immunohistochemically detected CD133+ cells with resistance to combined chemoradiation and decreased survival (Chiou et al. 2008). These data are supported by evaluations of glioma (Murat et al. 2008) and rectal cancer patients (Wang et al. 2009). All these studies show correlations between CD133 expression and efficacy of radiotherapy or combined treatment. Similarly, studies have also shown that CD133 positivity is associated with chemoresistance in glioma (Nakai et al. 2009), oral squamous cancer (Zhang et al.), and mesothelioma (Cortes-Dericks et al. 2010) amongst others. A large clinical study of 501 cases of human colorectal cancers showed that CD133-overexpressing tumors were more resistant to 5-FU-based chemotherapy and that CD133 expression was associated with poor prognosis (Ong et al. 2010). A recent study showed that treatment of human HT-29 colorectal cancer cells with high doses of 5-FU or oxaliplatin resulted in enrichment of CD133+ and CD44+ CSCs, which also exhibited decreased in vitro proliferation rate (Dallas et al. 2009). Interestingly in another colorectal cell line study, a recent publication has suggested that although CD133+ cells had higher in vivo tumor-forming ability than CD133cells, it was the CD133- cells that were more resistant to 5-fluorouracil (FU) treatment (Hongo et al. 2011).

Although newer targeted agents such as cetuximab and bevacizumab are being tested in both frontline (Minsky et al. 2010) therapy and the metastatic setting (Cunningham et al. 2004; Hurwitz et al. 2004), they have modest effects on disease-free survival and overall survival. It would seem that the current combined modality therapies for rectal cancer will not be effective against CSCs no matter what combination is used. However, the most effective method to target CSCs has yet to be elucidated, but a number of possibilities exist including the administration of differentiating agents such as salinomycin (Gupta et al. 2009), targeting the specific signaling pathways of the CSCs (hedgehog, wnt, Notch) with drugs like cyclopamine (Merchant and Matsui 2010; Pannuti et al. 2010; Takahashi-Yanaga and Kahn 2010), targeting the microenvironmental niche of CSCs (LaBarge 2010), targeting the DNA checkpoint response (Frosina 2009), or using normal stem cells to home to the region of tumor (Hu et al. 2010). It is likely that future therapies will include inhibitors of survival pathways, along with immune cells, differentiation agents, and cytotoxic drugs, as a combination.

Immunological approaches have been demonstrated to be effective against CSCs in colorectal cancer. It has been shown that inhibiting the IL-4 signaling transduction pathway with an anti-IL-4 neutralizing antibody or an IL-4 receptor a antagonist sensitized CSCs to chemotherapeutics through down-regulation of anti-apoptotic proteins, such as cFLIP, Bcl$x L$, and PED (Todaro et al. 2007). The same group has also shown that incubation of colon CSCs with the bisphosphonate zoledronate induced an efficient $\gamma \delta$ T-cell response. These immune cells have been shown to be effective at killing different tumor cells in vitro, but this was the first report of using $\gamma \delta$ T-cell to target CSCs (Todaro et al. 2009).

Another important area of future investigation will be to determine the optimal timing of CSC-targeted therapies with other modalities, i.e. should it be co-administration of agents for newly diagnosed tumor or sequential scheduling after a remission to standard treatment has been obtained or at the time of progression after a standard treatment (Al-Hajj et al. 2004). A crucial element in optimizing timing will be the development of novel imaging probes to develop strategies for robust and efficient tracking and validation of CSCs and their niche under in vivo conditions. This will pave the way to better elucidate the 
underlying regulatory mechanisms of CSC and develop platforms for targeted theragnostics.

\section{Conclusions}

The CSC model, if generally correct, has important implications for the current paradigm of treatment for rectal cancer. The practice of small, successive improvements in survival by the refinement of current schedules and addition of newer agents is unlikely to result in significant advances in treatment outcomes. Gene expression analyses of CSCs populations have the possibility to identify novel diagnostic markers and novel therapeutic targets. A recent study identified EGR1 to the be the most highly expressed gene in CD133 positive colorectal cancer cells (Ernst et al. 2011). EGR1 is known to regulate Wnt through upregulation of TCF4, which induces stem cell marker LGR5. Previous studies identified 100 candidate-genes, which were differentially expressed in the CD133 positive fraction (Regenbrecht et al. 2008) of which 10 genes were shown to be differentially regulated between the different studies. However, 9 of these 10 genes were shown to form an interactive network with each other and that these genes were positioned at the interface between proliferative pathways (JAK/STAT) and differentiating pathways (HOX, PBX, MEIS, GATA2). Of importance in this cascade was the gene KIT which encodes the receptor for stem cell factor (SCF). It is clear from Figure 5 that CD133 is involved in many signaling pathways and identifying the candidate pathways for future drug development will be challenging. Equally challenging will be targeting pathways of stem cell self renewal without affecting this crucial process in normal stem cells. Thus, the elucidation of the mechanisms regulating the survival, self-renewal, and differentiation of normal and CSCs could potentially lead to significant advances in the treatment of neoplastic diseases including rectal cancer.

\section{References}

Al-Hajj, M., M. W. Becker, M. Wicha, I. Weissman and M. F. Clarke (2004). Therapeutic implications of cancer stem cells. Current Opinion in Genetics and Development, Vol.14, No.(1), pp. 43-47, ISSN 0959-437X

Al-Hajj, M., M. S. Wicha, A. Benito-Hernandez, S. J. Morrison and M. F. Clarke (2003). Prospective identification of tumorigenic breast cancer cells. Proceedings of the National Academy of Sciences of the United States of America, Vol.100, No.(7), pp. 39833988, ISSN 0027-8424

Auclair, B. A., Y. D. Benoit, N. Rivard, Y. Mishina and N. Perreault (2007). Bone morphogenetic protein signaling is essential for terminal differentiation of the intestinal secretory cell lineage. Gastroenterology, Vol.133, No.(3), pp. 887-896, ISSN 0016-5085

Axelrod, R., D. E. Axelrod and K. J. Pienta (2006). Evolution of cooperation among tumor cells. Proceedings of the National Academy of Sciences of the United States of America, Vol.103, No.(36), pp. 13474-13479, ISSN 0027-8424

Baker, S. J., A. C. Preisinger, J. M. Jessup, C. Paraskeva, S. Markowitz, J. K. Willson, S. Hamilton and B. Vogelstein (1990). p53 gene mutations occur in combination with 
$17 \mathrm{p}$ allelic deletions as late events in colorectal tumorigenesis. Cancer Research, Vol.50, No.(23), pp. 7717-7722, ISSN 0008-5472

Bao, S., Q. Wu, R. E. McLendon, Y. Hao, Q. Shi, A. B. Hjelmeland, M. W. Dewhirst, D. D. Bigner and J. N. Rich (2006). Glioma stem cells promote radioresistance by preferential activation of the DNA damage response. Nature, Vol.444, No.(7120), pp. 756-760, ISSN 1476-4687

Barker, N., J. H. van Es, J. Kuipers, P. Kujala, M. van den Born, M. Cozijnsen, A. Haegebarth, J. Korving, H. Begthel, P. J. Peters and H. Clevers (2007). Identification of stem cells in small intestine and colon by marker gene Lgr5. Nature, Vol.449, No.(7165), pp. 1003-1007, ISSN 1476-4687

Bertolini, G., L. Roz, P. Perego, M. Tortoreto, E. Fontanella, L. Gatti, G. Pratesi, A. Fabbri, F. Andriani, S. Tinelli, E. Roz, R. Caserini, S. Lo Vullo, T. Camerini, L. Mariani, D. Delia, E. Calabro, U. Pastorino and G. Sozzi (2009). Highly tumorigenic lung cancer CD133+ cells display stem-like features and are spared by cisplatin treatment. Proceedings of the National Academy of Sciences of the United States of America, Vol.106, No.(38), pp. 16281-16286, ISSN 0027-8424

Boman, B. M., J. Z. Fields, O. Bonham-Carter and O. A. Runquist (2001). Computer modeling implicates stem cell overproduction in colon cancer initiation. Cancer Research, Vol.61, No.(23), pp. 8408-8411, ISSN 0008-5472

Boman, B. M. and E. Huang (2008). Human colon cancer stem cells: a new paradigm in gastrointestinal oncology. Journal of Clinical Oncology, Vol.26, No.(17), pp. 28282838, ISSN 0732-183X

Bonnet, D. and J. E. Dick (1997). Human acute myeloid leukemia is organized as a hierarchy that originates from a primitive hematopoietic cell. Nature Medicine, Vol.3, No.(7), pp. 730-737, ISSN 1078-8956

Brabletz, S., O. Schmalhofer and T. Brabletz (2009). Gastrointestinal stem cells in development and cancer. Journal of Pathology, Vol.217, No.(2), pp. 307-317, ISSN 0022-3417

Bray, S. J. (2006). Notch signalling: a simple pathway becomes complex. Nature Reviews Molecular Cell Biology, Vol.7, No.(9), pp. 678-689, ISSN 1471-0072

Chen, S. Y., Y. C. Huang, S. P. Liu, F. J. Tsai, W. C. Shyu and S. Z. Lin (2011). An overview of concepts for cancer stem cells. Cell Transplantation, Vol.20, No.(1), pp. 113-120, 1555ISSN 0963-6897

Chiou, S. H., C. L. Kao, Y. W. Chen, C. S. Chien, S. C. Hung, J. F. Lo, Y. J. Chen, H. H. Ku, M. T. Hsu and T. T. Wong (2008). Identification of CD133-positive radioresistant cells in atypical teratoid/rhabdoid tumor. PLoS One, Vol.3, No.(5), pp. e2090, ISSN 19326203

Clay, M. R., M. Tabor, J. H. Owen, T. E. Carey, C. R. Bradford, G. T. Wolf, M. S. Wicha and M. E. Prince (2010). Single-marker identification of head and neck squamous cell carcinoma cancer stem cells with aldehyde dehydrogenase. Head and Neck, Vol.32, No.(9), pp. 1195-1201, ISSN 1043-3074

Clevers, H. The cancer stem cell: premises, promises and challenges (2011). Nature Medicine, Vol.17, No.(3), pp. 313-319, ISSN 1078-8956

Cortes-Dericks, L., G. L. Carboni, R. A. Schmid and G. Karoubi (2010). Putative cancer stem cells in malignant pleural mesothelioma show resistance to cisplatin and 
pemetrexed. International Journal of Oncology, Vol.37, No.(2), pp. 437-444, ISSN 10196439

Cunningham, D., Y. Humblet, S. Siena, D. Khayat, H. Bleiberg, A. Santoro, D. Bets, M. Mueser, A. Harstrick, C. Verslype, I. Chau and E. Van Cutsem (2004). Cetuximab monotherapy and cetuximab plus irinotecan in irinotecan-refractory metastatic colorectal cancer. New England Journal of Medicine, Vol.351, No.(4), pp. 337-345, ISSN 0028-4793

Dalerba, P., S. J. Dylla, I. K. Park, R. Liu, X. Wang, R. W. Cho, T. Hoey, A. Gurney, E. H. Huang, D. M. Simeone, A. A. Shelton, G. Parmiani, C. Castelli and M. F. Clarke (2007). Phenotypic characterization of human colorectal cancer stem cells. Proceedings of the National Academy of Sciences of the United States of America, Vol.104, No.(24), pp. 10158-10163, ISSN 0027-8424

Dallas, N. A., L. Xia, F. Fan, M. J. Gray, P. Gaur, G. van Buren, 2nd, S. Samuel, M. P. Kim, S. J. Lim and L. M. Ellis (2009). Chemoresistant colorectal cancer cells, the cancer stem cell phenotype, and increased sensitivity to insulin-like growth factor-I receptor inhibition. Cancer Research, Vol.69, No.(5), pp. 1951-1957, ISSN 0008-5472

Dean, M., T. Fojo and S. Bates (2005). Tumour stem cells and drug resistance. Nature Reviews Cancer, Vol.5, No.(4), pp. 275-284, ISSN 1474-175X

Dontu, G., S. Liu and M. S. Wicha (2005). Stem cells in mammary development and carcinogenesis: implications for prevention and treatment. Stem Cell Reviews, Vol.1, No.(3), pp. 207-213, ISSN 1550-8943

Enblad, P., H. O. Adami, R. Bergstrom, B. Glimelius, U. Krusemo and L. Pahlman (1988). Improved survival of patients with cancers of the colon and rectum? Journal of the National Cancer Institute, Vol.80, No.(8), pp. 586-591, ISSN 0027-8874

Ernst, A., M. Aigner, S. Nakata, F. Engel, M. Schlotter, M. Kloor, K. Brand, S. Schmitt, G. Steinert, N. Rahbari, M. Koch, B. Radlwimmer, J. Weitz and P. Lichter (2011). A gene signature distinguishing CD133hi from CD133- colorectal cancer cells: essential role for EGR1 and downstream factors. Pathology, Vol.43, No.(3), pp. 220227, ISSN 0031-3025

Fearon, E. R. and B. Vogelstein (1990). A genetic model for colorectal tumorigenesis. Cell, Vol.61, No.(5), pp. 759-767, ISSN 0092-8674

Fernebro, E., P. O. Bendahl, M. Dictor, A. Persson, M. Ferno and M. Nilbert (2004). Immunohistochemical patterns in rectal cancer: application of tissue microarray with prognostic correlations. International Journal of Cancer, Vol.111, No.(6), pp. 921ISSN 0020-7136

Fevr, T., S. Robine, D. Louvard and J. Huelsken (2007). Wnt/beta-catenin is essential for intestinal homeostasis and maintenance of intestinal stem cells. Molecular and Cellular Biology, Vol.27, No.(21), pp. 7551-7559, ISSN 0270-7306

Frattini, M., D. Balestra, S. Suardi, M. Oggionni, P. Alberici, P. Radice, A. Costa, M. G. Daidone, E. Leo, S. Pilotti, L. Bertario and M. A. Pierotti (2004). Different genetic features associated with colon and rectal carcinogenesis. Clinical Cancer Research, Vol.10, No.(12 Pt 1), pp. 4015-4021, ISSN 1078-0432

Frosina, G. (2009). DNA repair and resistance of gliomas to chemotherapy and radiotherapy. Molecular Cancer Research, Vol.7, No.(7), pp. 989-999, ISSN 1541-7786 
Gazzaniga, P., E. Cigna, V. Panasiti, V. Devirgiliis, U. Bottoni, B. Vincenzi, C. Nicolazzo, A. Petracca and A. Gradilone (2010). CD133 and ABCB5 as stem cell markers on sentinel lymph node from melanoma patients. European Journal of Surgical Oncology, Vol.36, No.(12), pp. 1211-1214, ISSN 0748-7983

Glimelius, B. and J. Oliveira (2009). Rectal cancer: ESMO clinical recommendations for diagnosis, treatment and follow-up. Annals of Oncology, Vol.20 Suppl 4, pp. 54-56, ISSN 0923-7534

Gupta, P. B., T. T. Onder, G. Jiang, K. Tao, C. Kuperwasser, R. A. Weinberg and E. S. Lander (2009). Identification of selective inhibitors of cancer stem cells by high-throughput screening. Cell, Vol.138, No.(4), pp. 645-659, ISSN 0092-8674

Harper, L. J., K. Piper, J. Common, F. Fortune and I. C. Mackenzie (2007). Stem cell patterns in cell lines derived from head and neck squamous cell carcinoma. Journal of Oral Pathology and Medicine, Vol.36, No.(10), pp. 594-603, ISSN 0904-2512

He, X. C., J. Zhang, W. G. Tong, O. Tawfik, J. Ross, D. H. Scoville, Q. Tian, X. Zeng, X. He, L. M. Wiedemann, Y. Mishina and L. Li (2004). BMP signaling inhibits intestinal stem cell self-renewal through suppression of Wnt-beta-catenin signaling. Nature Genetics, Vol.36, No.(10), pp. 1117-1121, ISSN 1061-4036

Hongo, K., J. Tanaka, N. H. Tsuno, K. Kawai, T. Nishikawa, Y. Shuno, K. Sasaki, M. Kaneko, M. Hiyoshi, E. Sunami, J. Kitayama, K. Takahashi and H. Nagawa (2011). CD133(-) Cells, Derived From a Single Human Colon Cancer Cell Line, Are More Resistant to 5-Fluorouracil (FU) Than CD133(+) Cells, Dependent on the beta1-Integrin Signaling. Journal of Surgical Research, ISSN 0022-4804

Hosonuma, S., Y. Kobayashi, S. Kojo, H. Wada, K. Seino, K. Kiguchi and B. Ishizuka (2011). Clinical significance of side population in ovarian cancer cells. Human Cell, Vol.24, No.(1), pp. 9-12, ISSN 0914-7470

Hu, Y. L., Y. H. Fu, Y. Tabata and J. Q. Gao (2010). Mesenchymal stem cells: a promising targeted-delivery vehicle in cancer gene therapy. Journal of Controlled Release, Vol.147, No.(2), pp. 154-162, ISSN 0168-3659

Huang, E. H., M. J. Hynes, T. Zhang, C. Ginestier, G. Dontu, H. Appelman, J. Z. Fields, M. S. Wicha and B. M. Boman (2009). Aldehyde dehydrogenase 1 is a marker for normal and malignant human colonic stem cells (SC) and tracks SC overpopulation during colon tumorigenesis. Cancer Research, Vol.69, No.(8), pp. 3382-3389, ISSN 0008-5472

Humphries, A. and N. A. Wright (2008). Colonic crypt organization and tumorigenesis. Nature Reviews Cancer, Vol.8, No.(6), pp. 415-424, ISSN 1474-175X

Hurwitz, H., L. Fehrenbacher, W. Novotny, T. Cartwright, J. Hainsworth, W. Heim, J. Berlin, A. Baron, S. Griffing, E. Holmgren, N. Ferrara, G. Fyfe, B. Rogers, R. Ross and F. Kabbinavar (2004). Bevacizumab plus irinotecan, fluorouracil, and leucovorin for metastatic colorectal cancer. New England Journal of Medicine, Vol.350, No.(23), pp. 2335-2342, ISSN 0028-4793

Jensen, J., E. E. Pedersen, P. Galante, J. Hald, R. S. Heller, M. Ishibashi, R. Kageyama, F. Guillemot, P. Serup and O. D. Madsen (2000). Control of endodermal endocrine development by Hes-1. Nature Genetics, Vol.24, No.(1), pp. 36-44, ISSN 1061-4036

Jones, S., W. D. Chen, G. Parmigiani, F. Diehl, N. Beerenwinkel, T. Antal, A. Traulsen, M. A. Nowak, C. Siegel, V. E. Velculescu, K. W. Kinzler, B. Vogelstein, J. Willis and S. D. Markowitz (2008). Comparative lesion sequencing provides insights into tumor 
evolution. Proceedings of the National Academy of Sciences of the United States of America, Vol.105, No.(11), pp. 4283-4288, ISSN 0027-8424

Juarez, J. and L. Bendall (2004). SDF-1 and CXCR4 in normal and malignant hematopoiesis. Histology and Histopathology, Vol.19, No.(1), pp. 299-309, ISSN 0213-3911

Kalabis, J., K. Oyama, T. Okawa, H. Nakagawa, C. Z. Michaylira, D. B. Stairs, J. L. Figueiredo, U. Mahmood, J. A. Diehl, M. Herlyn and A. K. Rustgi (2008). A subpopulation of mouse esophageal basal cells has properties of stem cells with the capacity for self-renewal and lineage specification. Journal of Clinical Investigation, Vol.118, No.(12), pp. 3860-3869, ISSN 0021-9738

Kalady, M. F., K. Dejulius, J. M. Church, I. C. Lavery, V. W. Fazio and H. Ishwaran (2010). Gene signature is associated with early stage rectal cancer recurrence. Journal of the American College of Surgeons, Vol.211, No.(2), pp. 187-195, ISSN 1072-7515

Kapiteijn, E., G. J. Liefers, L. C. Los, E. K. Kranenbarg, J. Hermans, R. A. Tollenaar, Y. Moriya, C. J. van de Velde and J. H. van Krieken (2001). Mechanisms of oncogenesis in colon versus rectal cancer. Journal of Pathology, Vol.195, No.(2), pp. 171-178, ISSN 0022-3417

Kim, M. P., J. B. Fleming, H. Wang, J. L. Abbruzzese, W. Choi, S. Kopetz, D. J. McConkey, D. B. Evans and G. E. Gallick (2011). ALDH Activity Selectively Defines an Enhanced Tumor-Initiating Cell Population Relative to CD133 Expression in Human Pancreatic Adenocarcinoma. PLoS One, Vol.6, No.(6), pp. e20636, ISSN 1932-6203

Kojima, M., G. Ishii, N. Atsumi, Y. Nishizawa, N. Saito and A. Ochiai (2010). CD133 expression in rectal cancer after preoperative chemoradiotherapy. Cancer Science, Vol.101, No.(4), pp. 906-912, ISSN 1347-9032

Korinek, V., N. Barker, P. Moerer, E. van Donselaar, G. Huls, P. J. Peters and H. Clevers (1998). Depletion of epithelial stem-cell compartments in the small intestine of mice lacking Tcf-4. Nature Genetics, Vol.19, No.(4), pp. 379-383, ISSN 1061-4036

Korinek, V., N. Barker, P. J. Morin, D. van Wichen, R. de Weger, K. W. Kinzler, B. Vogelstein and $\mathrm{H}$. Clevers (1997). Constitutive transcriptional activation by a beta-catenin-Tcf complex in APC-/- colon carcinoma. Science, Vol.275, No.(5307), pp. 1784-1787, ISSN 0036-8075

Kosinski, C., V. S. Li, A. S. Chan, J. Zhang, C. Ho, W. Y. Tsui, T. L. Chan, R. C. Mifflin, D. W. Powell, S. T. Yuen, S. Y. Leung and X. Chen (2007). Gene expression patterns of human colon tops and basal crypts and BMP antagonists as intestinal stem cell niche factors. Proceedings of the National Academy of Sciences of the United States of America, Vol.104, No.(39), pp. 15418-15423, ISSN 0027-8424

LaBarge, M. A. (2010). The difficulty of targeting cancer stem cell niches. Clinical Cancer Research, Vol.16, No.(12), pp. 3121-3129, ISSN 1078-0432

Lapidot, T., C. Sirard, J. Vormoor, B. Murdoch, T. Hoang, J. Caceres-Cortes, M. Minden, B. Paterson, M. A. Caligiuri and J. E. Dick (1994). A cell initiating human acute myeloid leukaemia after transplantation into SCID mice. Nature, Vol.367, No.(6464), pp. 645-648, ISSN 0028-0836

Lee, C. J., J. Dosch and D. M. Simeone (2008). Pancreatic cancer stem cells. Journal of Clinical Oncology, Vol.26, No.(17), pp. 2806-2812, ISSN 0732-183X

Li, F. Y. and M. D. Lai (2009). Colorectal cancer, one entity or three. Journal of Zhejiang University Science B, Vol.10, No.(3), pp. 219-229, ISSN 1673-1581 
Li, L. and T. Xie (2005). Stem cell niche: structure and function. Annual Review of Cell and Developmental Biology, Vol.21, pp. 605-631, ISSN 1081-0706

Liang, D. and Y. Shi (2011). Aldehyde dehydrogenase-1 is a specific marker for stem cells in human lung adenocarcinoma. Medical Oncology, ISSN 1357-0560

Madison, B. B., K. Braunstein, E. Kuizon, K. Portman, X. T. Qiao and D. L. Gumucio (2005). Epithelial hedgehog signals pattern the intestinal crypt-villus axis. Development, Vol.132, No.(2), pp. 279-289, ISSN 0950-1991

Marcato, P., C. A. Dean, D. Pan, R. Araslanova, M. Gillis, M. Joshi, L. Helyer, L. Pan, A. Leidal, S. Gujar, C. A. Giacomantonio and P. W. Lee (2011). Aldehyde dehydrogenase activity of breast cancer stem cells is primarily due to isoform ALDH1A3 and its expression is predictive of metastasis. Stem Cells, Vol.29, No.(1), pp. 32-45, ISSN 1066-5099

McCord, A. M., M. Jamal, E. S. Williams, K. Camphausen and P. J. Tofilon (2009). CD133+ glioblastoma stem-like cells are radiosensitive with a defective DNA damage response compared with established cell lines. Clinical Cancer Research, Vol.15, No.(16), pp. 5145-5153, ISSN 1078-0432

Merchant, A. A. and W. Matsui (2010). Targeting Hedgehog--a cancer stem cell pathway. Clinical Cancer Research, Vol.16, No.(12), pp. 3130-3140, ISSN 1078-0432

Miki, J., B. Furusato, H. Li, Y. Gu, H. Takahashi, S. Egawa, I. A. Sesterhenn, D. G. McLeod, S. Srivastava and J. S. Rhim (2007). Identification of putative stem cell markers, CD133 and CXCR4, in hTERT-immortalized primary nonmalignant and malignant tumorderived human prostate epithelial cell lines and in prostate cancer specimens. Cancer Research, Vol.67, No.(7), pp. 3153-3161, ISSN 0008-5472

Mills, J. C. and J. I. Gordon (2001). The intestinal stem cell niche: there grows the neighborhood. Proceedings of the National Academy of Sciences of the United States of America, Vol.98, No.(22), pp. 12334-12336, ISSN 0027-8424

Mimeault, M. and S. K. Batra (2011). Frequent Gene Products and Molecular Pathways Altered in Prostate Cancer- and Metastasis-Initiating Cells and their Progenies and Novel Promising Multitargeted Therapies. Molecular Medicine, ISSN 1076-1551

Minsky, B. D., C. Roedel and V. Valentini (2010). Combined modality therapy for rectal cancer. Cancer Journal, Vol.16, No.(3), pp. 253-261, ISSN 1528-9117

Murat, A., E. Migliavacca, T. Gorlia, W. L. Lambiv, T. Shay, M. F. Hamou, N. de Tribolet, L. Regli, W. Wick, M. C. Kouwenhoven, J. A. Hainfellner, F. L. Heppner, P. Y. Dietrich, Y. Zimmer, J. G. Cairncross, R. C. Janzer, E. Domany, M. Delorenzi, R. Stupp and M. E. Hegi (2008). Stem cell-related "self-renewal" signature and high epidermal growth factor receptor expression associated with resistance to concomitant chemoradiotherapy in glioblastoma. Journal of Clinical Oncology, Vol.26, No.(18), pp. 3015-3024, ISSN 0732-183X

Nagata, T., C. Sakakura, S. Komiyama, A. Miyashita, M. Nishio, Y. Murayama, S. Komatsu, A. Shiozaki, Y. Kuriu, H. Ikoma, M. Nakanishi, D. Ichikawa, H. Fujiwara, K. Okamoto, T. Ochiai, Y. Kokuba, T. Sonoyama and E. Otsuji (2011). Expression of cancer stem cell markers CD133 and CD44 in locoregional recurrence of rectal cancer. Anticancer Research, Vol.31, No.(2), pp. 495-500, ISSN 0250-7005

Nakai, E., K. Park, T. Yawata, T. Chihara, A. Kumazawa, H. Nakabayashi and K. Shimizu (2009). Enhanced MDR1 expression and chemoresistance of cancer stem cells 
derived from glioblastoma. Cancer Investigation, Vol.27, No.(9), pp. 901-908, ISSN 0735-7907

Nowell, P. C. (1976). The clonal evolution of tumor cell populations. Science, Vol.194, No.(4260), pp. 23-28, ISSN 0036-8075

O'Brien, C. A., A. Kreso and C. H. Jamieson (2010). Cancer stem cells and self-renewal. Clinical Cancer Research, Vol.16, No.(12), pp. 3113-3120, ISSN 1078-0432

O'Brien, C. A., A. Pollett, S. Gallinger and J. E. Dick (2007). A human colon cancer cell capable of initiating tumour growth in immunodeficient mice. Nature, Vol.445, No.(7123), pp. 106-110, ISSN 0028-0836

Ojima, E., Y. Inoue, C. Miki, M. Mori and M. Kusunoki (2007). Effectiveness of gene expression profiling for response prediction of rectal cancer to preoperative radiotherapy. Journal of Gastroenterology, Vol.42, No.(9), pp. 730-736, ISSN 0944-1174

Ong, C. W., L. G. Kim, H. H. Kong, L. Y. Low, B. Iacopetta, R. Soong and M. Salto-Tellez (2010). CD133 expression predicts for non-response to chemotherapy in colorectal cancer. Modern Pathology, Vol.23, No.(3), pp. 450-457, ISSN 0893-3952

Pages, F., A. Kirilovsky, B. Mlecnik, M. Asslaber, M. Tosolini, G. Bindea, C. Lagorce, P. Wind, F. Marliot, P. Bruneval, K. Zatloukal, Z. Trajanoski, A. Berger, W. H. Fridman and J. Galon (2009). In situ cytotoxic and memory T cells predict outcome in patients with early-stage colorectal cancer. Journal of Clinical Oncology, Vol.27, No.(35), pp. 5944-5951, ISSN 0732-183X

Pannuti, A., K. Foreman, P. Rizzo, C. Osipo, T. Golde, B. Osborne and L. Miele (2010). Targeting Notch to target cancer stem cells. Clinical Cancer Research, Vol.16, No.(12), pp. 3141-3152, ISSN 1078-0432

Parkin, D. M., F. Bray, J. Ferlay and P. Pisani (2005). Global cancer statistics, 2002. CA: A Cancer Journal for Clinicians, Vol.55, No.(2), pp. 74-108, ISSN 0007-9235

Persad, S., A. A. Troussard, T. R. McPhee, D. J. Mulholland and S. Dedhar (2001). Tumor suppressor PTEN inhibits nuclear accumulation of beta-catenin and $T$ cell/lymphoid enhancer factor 1-mediated transcriptional activation. Journal of Cell Biology, Vol.153, No.(6), pp. 1161-1174, ISSN 0021-9525

Pierce, G. B. and W. C. Speers (1988). Tumors as caricatures of the process of tissue renewal: prospects for therapy by directing differentiation. Cancer Research, Vol.48, No.(8), pp. 1996-2004, ISSN 0008-5472

Ponti, D., A. Costa, N. Zaffaroni, G. Pratesi, G. Petrangolini, D. Coradini, S. Pilotti, M. A. Pierotti and M. G. Daidone (2005). Isolation and in vitro propagation of tumorigenic breast cancer cells with stem/progenitor cell properties. Cancer Research, Vol.65, No.(13), pp. 5506-5511, ISSN 0008-5472

Popat, S., D. Zhao, Z. Chen, H. Pan, Y. Shao, I. Chandler and R. S. Houlston (2007). Relationship between chromosome $18 \mathrm{q}$ status and colorectal cancer prognosis: a prospective, blinded analysis of 280 patients. Anticancer Research, Vol.27, No.(1B), pp. 627-633, ISSN 0250-7005

Potten, C. S. (1998). Stem cells in gastrointestinal epithelium: numbers, characteristics and death. Philosophical Transactions of the Royal Society of London. Series B: Biological Sciences, Vol.353, No.(1370), pp. 821-830, ISSN 0962-8436 
Potten, C. S., C. Booth and D. M. Pritchard (1997). The intestinal epithelial stem cell: the mucosal governor. International Journal of Experimental Pathology, Vol.78, No.(4), pp. 219-243, ISSN 0959-9673

Potten, C. S., C. Booth, G. L. Tudor, D. Booth, G. Brady, P. Hurley, G. Ashton, R. Clarke, S. Sakakibara and H. Okano (2003). Identification of a putative intestinal stem cell and early lineage marker; musashi-1. Differentiation, Vol.71, No.(1), pp. 28-41, ISSN 0301-4681

Potten, C. S., M. Kellett, S. A. Roberts, D. A. Rew and G. D. Wilson (1992). Measurement of in vivo proliferation in human colorectal mucosa using bromodeoxyuridine. Gut, Vol.33, No.(1), pp. 71-78, ISSN 0017-5749

Potten, C. S. and M. Loeffler (1990). Stem cells: attributes, cycles, spirals, pitfalls and uncertainties. Lessons for and from the crypt. Development, Vol.110, No.(4), pp. 1001-1020, ISSN 0950-1991

Powell, S. M., N. Zilz, Y. Beazer-Barclay, T. M. Bryan, S. R. Hamilton, S. N. Thibodeau, B. Vogelstein and K. W. Kinzler (1992). APC mutations occur early during colorectal tumorigenesis. Nature, Vol.359, No.(6392), pp. 235-237, ISSN 0028-0836

Regenbrecht, C. R., H. Lehrach and J. Adjaye (2008). Stemming cancer: functional genomics of cancer stem cells in solid tumors. Stem Cell Reviews, Vol.4, No.(4), pp. 319-328, ISSN 1550-8943

Ricci-Vitiani, L., R. Pallini, M. Biffoni, M. Todaro, G. Invernici, T. Cenci, G. Maira, E. A. Parati, G. Stassi, L. M. Larocca and R. De Maria (2010). Tumour vascularization via endothelial differentiation of glioblastoma stem-like cells. Nature, Vol.468, No.(7325), pp. 824-828, ISSN 0028-0836

Rimkus, C., J. Friederichs, A. L. Boulesteix, J. Theisen, J. Mages, K. Becker, H. Nekarda, R. Rosenberg, K. P. Janssen and J. R. Siewert (2008). Microarray-based prediction of tumor response to neoadjuvant radiochemotherapy of patients with locally advanced rectal cancer. Clinical Gastroenterology and Hepatology, Vol.6, No.(1), pp. 53-61, ISSN 1542-3565

Saigusa, S., K. Tanaka, Y. Toiyama, T. Yokoe, Y. Okugawa, Y. Koike, H. Fujikawa, Y. Inoue, C. Miki and M. Kusunoki (2011). Clinical significance of CD133 and hypoxia inducible factor-1alpha gene expression in rectal cancer after preoperative chemoradiotherapy. Clinical Oncology (Royal College of Radiologists), Vol.23, No.(5), pp. 323-332, ISSN 0936-6555

Sangiorgi, E. and M. R. Capecchi (2009). Bmi1 lineage tracing identifies a self-renewing pancreatic acinar cell subpopulation capable of maintaining pancreatic organ homeostasis. Proceedings of the National Academy of Sciences of the United States of America, Vol.106, No.(17), pp. 7101-7106, ISSN 0027-8424

Sato, T., J. H. van Es, H. J. Snippert, D. E. Stange, R. G. Vries, M. van den Born, N. Barker, N. F. Shroyer, M. van de Wetering and H. Clevers (2011). Paneth cells constitute the niche for Lgr5 stem cells in intestinal crypts. Nature, Vol.469, No.(7330), pp. 415-418, ISSN 0028-0836

Sayed, M. G., A. F. Ahmed, J. R. Ringold, M. E. Anderson, J. L. Bair, F. A. Mitros, H. T. Lynch, S. T. Tinley, G. M. Petersen, F. M. Giardiello, B. Vogelstein and J. R. Howe (2002). Germline SMAD4 or BMPR1A mutations and phenotype of juvenile polyposis. Annals of Surgical Oncology, Vol.9, No.(9), pp. 901-906, ISSN 1068-9265 
Schulte, A., H. S. Gunther, H. S. Phillips, D. Kemming, T. Martens, S. Kharbanda, R. H. Soriano, Z. Modrusan, S. Zapf, M. Westphal and K. Lamszus (2011). A distinct subset of glioma cell lines with stem cell-like properties reflects the transcriptional phenotype of glioblastomas and overexpresses CXCR4 as therapeutic target. Glia, Vol.59, No.(4), pp. 590-602, ISSN 0894-1491

Scoville, D. H., T. Sato, X. C. He and L. Li (2008). Current view: intestinal stem cells and signaling. Gastroenterology, Vol.134, No.(3), pp. 849-864, ISSN 0016-5085

Silva, I. A., S. Bai, K. McLean, K. Yang, K. Griffith, D. Thomas, C. Ginestier, C. Johnston, A. Kueck, R. K. Reynolds, M. S. Wicha and R. J. Buckanovich (2011). Aldehyde Dehydrogenase in Combination with CD133 Defines Angiogenic Ovarian Cancer Stem Cells That Portend Poor Patient Survival. Cancer Research, Vol.71, No.(11), pp. 3991-4001, ISSN 0008-5472

Singh, S. K., C. Hawkins, I. D. Clarke, J. A. Squire, J. Bayani, T. Hide, R. M. Henkelman, M. D. Cusimano and P. B. Dirks (2004). Identification of human brain tumour initiating cells. Nature, Vol.432, No.(7015), pp. 396-401, ISSN 0028-0836

Spradling, A., D. Drummond-Barbosa and T. Kai (2001). Stem cells find their niche. Nature, Vol.414, No.(6859), pp. 98-104, ISSN 0028-0836

Sun, G., M. Fujii, A. Sonoda, Y. Tokumaru, T. Matsunaga and N. Habu (2010). Identification of stem-like cells in head and neck cancer cell lines. Anticancer Research, Vol.30, No.(6), pp. 2005-2010, ISSN 0250-7005

Takahashi-Yanaga, F. and M. Kahn (2010). Targeting Wnt signaling: can we safely eradicate cancer stem cells? Clinical Cancer Research, Vol.16, No.(12), pp. 3153-3162, ISSN 1078-0432

Takahashi, H., H. Ishii, N. Nishida, I. Takemasa, T. Mizushima, M. Ikeda, T. Yokobori, K. Mimori, H. Yamamoto, M. Sekimoto, Y. Doki and M. Mori (2011). Significance of Lgr5(+ve) cancer stem cells in the colon and rectum. Annals of Surgical Oncology, Vol.18, No.(4), pp. 1166-1174, ISSN 1068-9265

Taylor, R. W., M. J. Barron, G. M. Borthwick, A. Gospel, P. F. Chinnery, D. C. Samuels, G. A. Taylor, S. M. Plusa, S. J. Needham, L. C. Greaves, T. B. Kirkwood and D. M. Turnbull (2003). Mitochondrial DNA mutations in human colonic crypt stem cells. Journal of Clinical Investigation, Vol.112, No.(9), pp. 1351-1360, ISSN 00219738

Thliveris, A. T., R. B. Halberg, L. Clipson, W. F. Dove, R. Sullivan, M. K. Washington, S. Stanhope and M. A. Newton (2005). Polyclonality of familial murine adenomas: analyses of mouse chimeras with low tumor multiplicity suggest short-range interactions. Proceedings of the National Academy of Sciences of the United States of America, Vol.102, No.(19), pp. 6960-6965, ISSN 0027-8424

Todaro, M., M. P. Alea, A. B. Di Stefano, P. Cammareri, L. Vermeulen, F. Iovino, C. Tripodo, A. Russo, G. Gulotta, J. P. Medema and G. Stassi. (2007). Cell Stem Cell, Vol. 1, No. (4), pp. 389-402, ISSN 1875-9777

Todaro, M., M. D'Asaro, N. Caccamo, F. Iovino, M. G. Francipane, S. Meraviglia, V. Orlando, C. La Mendola, G. Gulotta, A. Salerno, F. Dieli and G. Stassi (2009). Efficient killing of human colon cancer stem cells by gammadelta $\mathrm{T}$ lymphocytes. The Journal of Immunology, Vol. 182, No. 11, pp. 7287-7296, ISSN 1550-6606 
Vo, D. M., L. A. Julien and A. G. Thorson (2010). Current controversies in colon and rectal cancer. Minerva Chirurgica, Vol.65, No.(6), pp. 677-693, ISSN 0026-4733

Vogelstein, B., E. R. Fearon, S. R. Hamilton, S. E. Kern, A. C. Preisinger, M. Leppert, Y. Nakamura, R. White, A. M. Smits and J. L. Bos (1988). Genetic alterations during colorectal-tumor development. New England Journal of Medicine, Vol.319, No.(9), pp. 525-532, ISSN 0028-4793

von Bubnoff, A. and K. W. Cho (2001). Intracellular BMP signaling regulation in vertebrates: pathway or network? Developmental Biology, Vol.239, No.(1), pp. 1-14, ISSN 00121606

Wang, Q., Z. G. Chen, C. Z. Du, H. W. Wang, L. Yan and J. Gu (2009). Cancer stem cell marker CD133+ tumour cells and clinical outcome in rectal cancer. Histopathology, Vol.55, No.(3), pp. 284-293, ISSN 0309-0167

Wang, X., C. Venugopal, B. Manoranjan, N. McFarlane, E. O'Farrell, S. Nolte, T. Gunnarsson, R. Hollenberg, J. Kwiecien, P. Northcott, M. D. Taylor, C. Hawkins and S. K. Singh (2011). Sonic hedgehog regulates Bmi1 in human medulloblastoma brain tumorinitiating cells. Oncogene, ISSN 0950-9232

Wasan, H. S., H. S. Park, K. C. Liu, N. K. Mandir, A. Winnett, P. Sasieni, W. F. Bodmer, R. A. Goodlad and N. A. Wright (1998). APC in the regulation of intestinal crypt fission. Journal of Pathology, Vol.185, No.(3), pp. 246-255, ISSN 0022-3417

Watanabe, T., Y. Komuro, T. Kiyomatsu, T. Kanazawa, Y. Kazama, J. Tanaka, T. Tanaka, Y. Yamamoto, M. Shirane, T. Muto and H. Nagawa (2006). Prediction of sensitivity of rectal cancer cells in response to preoperative radiotherapy by DNA microarray analysis of gene expression profiles. Cancer Research, Vol.66, No.(7), pp. 3370-3374, ISSN 0008-5472

Wicha, M. S., S. Liu and G. Dontu (2006). Cancer stem cells: an old idea--a paradigm shift. Cancer Research, Vol.66, No.(4), pp. 1883-1890; discussion 1895-1886, ISSN 00085472

Yang, C. Y., C. H. Lin and J. K. Jiang (2010). Early relapse in a rectal cancer patient: possible implication of circulating cancer stem cell. Journal of Surgical Oncology, Vol.102, No.(2), pp. 196-197, ISSN 0022-4790

Yang, J. P., Y. Liu, W. Zhong, D. Yu, L. J. Wen and C. S. Jin (2011). Chemoresistance of CD133+ cancer stem cells in laryngeal carcinoma. Chinese Medical Journal (English), Vol.124, No.(7), pp. 1055-1060, ISSN 0366-6999

Yang, Q., N. A. Bermingham, M. J. Finegold and H. Y. Zoghbi (2001). Requirement of Math1 for secretory cell lineage commitment in the mouse intestine. Science, Vol.294, No.(5549), pp. 2155-2158, ISSN 0036-8075

Yasuda, H., K. Tanaka, S. Saigusa, Y. Toiyama, Y. Koike, Y. Okugawa, T. Yokoe, A. Kawamoto, Y. Inoue, C. Miki and M. Kusunoki (2009). Elevated CD133, but not VEGF or EGFR, as a predictive marker of distant recurrence after preoperative chemoradiotherapy in rectal cancer. Oncology Reports, Vol.22, No.(4), pp. 709-717, ISSN 1021-335X

Yin, A. H., S. Miraglia, E. D. Zanjani, G. Almeida-Porada, M. Ogawa, A. G. Leary, J. Olweus, J. Kearney and D. W. Buck (1997). AC133, a novel marker for human hematopoietic stem and progenitor cells. Blood, Vol.90, No.(12), pp. 5002-5012, ISSN 0006-4971 
Zabierowski, S. E. and M. Herlyn (2008). Melanoma stem cells: the dark seed of melanoma. Journal of Clinical Oncology, Vol.26, No.(17), pp. 2890-2894, ISSN 0732-183X

Zhang, F., C. Song, Y. Ma, L. Tang, Y. Xu and H. Wang (2011). Effect of fibroblasts on breast cancer cell mammosphere formation and regulation of stem cell-related gene expression. International Journal of Molecular Medicine, Vol.28, No.(3), pp. 365-371, ISSN 1107-3756

Zhang, Q., S. Shi, Y. Yen, J. Brown, J. Q. Ta and A. D. Le A subpopulation of CD133(+) cancer stem-like cells characterized in human oral squamous cell carcinoma confer resistance to chemotherapy (2010). Cancer Letters, Vol.289, No.(2), pp. 151-160, ISSN 0304-3835 


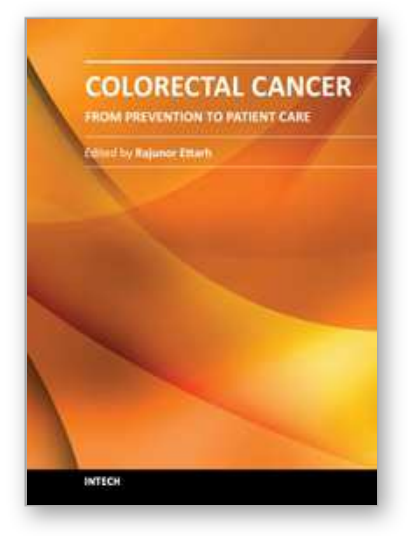

\author{
Colorectal Cancer - From Prevention to Patient Care \\ Edited by Dr. Rajunor Ettarh
}

ISBN 978-953-51-0028-7

Hard cover, 538 pages

Publisher InTech

Published online 17, February, 2012

Published in print edition February, 2012

The projections for future growth in the number of new patients with colorectal cancer in most parts of the world remain unfavorable. When we consider the substantial morbidity and mortality that accompanies the disease, the acute need for improvements and better solutions in patient care becomes evident. This volume, organized in five sections, represents a synopsis of the significant efforts from scientists, clinicians and investigators towards finding improvements in different patient care aspects including nutrition, diagnostic approaches, treatment strategies with the addition of some novel therapeutic approaches, and prevention. For scientists involved in investigations that explore fundamental cellular events in colorectal cancer, this volume provides a framework for translational integration of cell biological and clinical information. Clinicians as well as other healthcare professionals involved in patient management for colorectal cancer will find this volume useful.

\title{
How to reference
}

In order to correctly reference this scholarly work, feel free to copy and paste the following:

George D. Wilson and Bryan J. Thibodeau (2012). The Stem Cell Environment: Kinetics, Signaling and Markers, Colorectal Cancer - From Prevention to Patient Care, Dr. Rajunor Ettarh (Ed.), ISBN: 978-953-510028-7, InTech, Available from: http://www.intechopen.com/books/colorectal-cancer-from-prevention-topatient-care/the-significance-of-stem-cell-for-rectal-cancer-treatment

\section{INTECH}

open science | open minds

\author{
InTech Europe \\ University Campus STeP Ri \\ Slavka Krautzeka 83/A \\ 51000 Rijeka, Croatia \\ Phone: +385 (51) 770447 \\ Fax: +385 (51) 686166 \\ www.intechopen.com
}

\author{
InTech China \\ Unit 405, Office Block, Hotel Equatorial Shanghai \\ No.65, Yan An Road (West), Shanghai, 200040, China \\ 中国上海市延安西路65号上海国际贵都大饭店办公楼 405 单元 \\ Phone: +86-21-62489820 \\ Fax: $+86-21-62489821$
}


(C) 2012 The Author(s). Licensee IntechOpen. This is an open access article distributed under the terms of the Creative Commons Attribution 3.0 License, which permits unrestricted use, distribution, and reproduction in any medium, provided the original work is properly cited. 